\title{
A CADAVERIC STUDY ON MORPHOLOGICAL VARIATIONS OF
} LOBAR AND HILAR ANATOMY OF HUMAN LUNGS

\author{
Nishita K Jethva ${ }^{1}$, Hiren S Chavda *2. \\ ${ }^{1}$ Tutor, Department of Anatomy, GMERS Medical College, Gandhinagar, Gujarat, India. \\ ${ }^{* 2}$ Assistant Professor, Department of Anatomy, GMERS Medical College, Gandhinagar, Gujarat, \\ India.
}

\section{ABSTRACT}

Background: Knowledge of variations in fissures and hilar structures of the lungs is necessary for the appreciation of lobar anatomy and hilar anatomy of lungs.

Materials and Methods: Morphological variations of fissures, lobar and hilar structures were studied in 50 formalin fixed lungs belonged to $40-80$ years age group.

Results: In the present study following observation was made: Right sided lungs had, Incomplete Horizontal fissures in 7 lungs, absent horizontal fissures in 2 lungs, among Hilar structures 2 arteries in 5 lungs, 3 veins in 2 lungs, 1 bronchus in 2 lungs. Left sided lungs had, Incomplete horizontal fissures in 2 lungs, among hilar structures, 1 vein in 2 lungs, 3 vein in 2 lungs and 2 bronchus in 7 lungs.

Conclusion: Awareness regarding variations in fissures, lobes and hilar anatomy of the lungs is important clinically while interpreting the radiological images as well as to plan various surgical procedures to avoid postoperative complications.

KEY WORDS: Lung, Fissures, Hilum.

Address for Correspondence: Dr. Hiren S Chavda, Assistant Professor, Department of Anatomy, GMERS Medical College, Gandhinagar- 382012, Gujarat, India. Mobile No : 9979098428

E-Mail: hirenchavdahc999@gmail.com

Access this Article online

Quick Response code

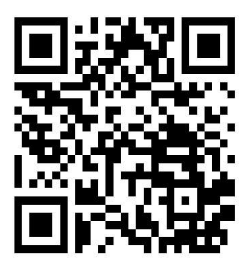

DOI: $10.16965 /$ ijar.2018.436

Journal Information

International Journal of Anatomy and Research

\begin{tabular}{|c|c|}
$\begin{array}{c}\text { ICV for } 2016 \\
\mathbf{9 0 . 3 0}\end{array}$ & $\begin{array}{c}\text { ISSN (E) 2321-4287 I ISSN (P) 2321-8967 } \\
\text { https://www.ijmhr.org/ijar.htm } \\
\text { DOI-Prefix: https://dx.doi.org/10.16965/ijar }\end{array} \quad$ (cc) EY-Mi-BA
\end{tabular}

Article Information

Received: 03 Dec 2018

Peer Review: 04 Dec 2018

Revised: None
Accepted: 03 Jan 2019

Published (O): 05 Feb 2019

Published (P): 05 Feb 2019

\section{BACKGROUND}

The lungs are essesntial organs of respiration and are situated in the thoracic cavity on either side of the mediastinum. Being vital organs of respiration, the lungs are devided into lobes by fissures which facilitate movements of lobes in relation to one another. The right lung is divided into 3 lobes- upper, middle and lower by oblique and horizontal fissures, the left lung is divided into 2 lobes- upper and middle by oblique fissure [1].

The fissures are complete, when the lobes remain held together only at the hilum by the bronchi and pulmonary vessels, or they may be incomplete when there are areas of parenchymal fusion between the lobes, or, they may be altogether absent.

The arrangement of fissures dividing lung tissues into lobes facilitates the movements of the lobes in relation to one another thus helping in uniform expansion of the whole lung in inspiration [2]. On mediastinal surface each lung shows a triangular depression called as hilum, where the structures which form the root of the lung enter and leave the lungs. Both the lungs admit 2 pulmonary veins and 1 pulmonary artery through the hilum. In the right hilum 
there are 2 bronchii- eparterial bronchus(above the level of pulmonary artery) and hyparterial bronchus(below the level of pulmonary artery). In the left hilum there is only 1 bronchus.

Understanding of normal anatomy is very essential foundation of the surgical knowledge. The awareness of variations in fissures and lobes is essential in performing lobectomies and in segmental resections as well as significant in interpreting radiological images. The fissures and the lobar variation of lungs are studied in a few populations, the hilar anatomy of the lungs has been overlooked [3].

In the current study, we focused on the morphological variations of the lungs in the Gujarat population.

Fig. 1: Normal pattern of lung fissures (a and c-costal surface of right and left lungs respectively, $b$ and $d$-medial surface of right and left lungs respectively).
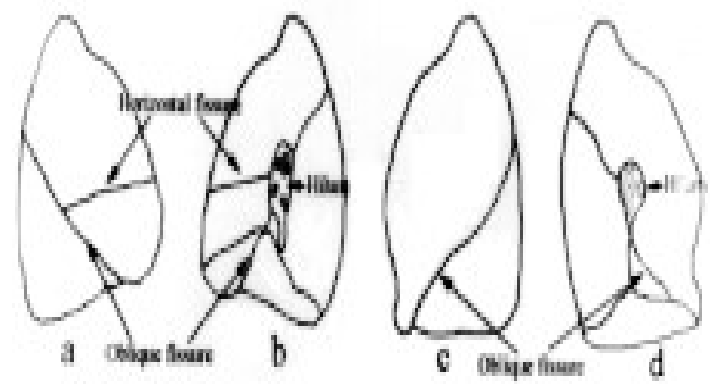

\section{MATERIALS AND METHODS}

Fifty formalin fixed lungs dissected from cadavers used for undergraduate dissection classes were observed for the study. The lungs belonged to age group between $40-80$ years. Gender difference of the lungs was not made in the study. Only those lungs which were covered all around by pleura were included in the study. Lungs damaged or if any part of the lung was cut off during its removal, such lung was excluded from the study. Out of fifty, twenty five right and twenty five left lungs were used in the study. Following parameters were observed in the study:

1. Number of Fissures.

2. Number of Lobes.

3. Variations in the Hilar structures.

\section{RESULTS}

The observations of morphological variation in lobar and hilar anatomy of all Lungs were done separately and enumerated in Tables below.

\begin{tabular}{|c|c|c|c|}
\hline \multirow{17}{*}{$\begin{array}{l}\text { Table 1: Varia- } \\
\text { tions seen in } \\
\text { Right Lungs. }\end{array}$} & \multicolumn{3}{|l|}{ Right Lungs ( $n=25$ ) } \\
\hline & Feature & No. & $\%$ \\
\hline & \multicolumn{3}{|l|}{ Oblique Fissure } \\
\hline & Complete & 25 & 100 \\
\hline & \multicolumn{3}{|l|}{ Horizontal Fissure } \\
\hline & Complete & 16 & 64 \\
\hline & Incomplete & 7 & 28 \\
\hline & Absent & 2 & 8 \\
\hline & \multicolumn{3}{|l|}{ Structures in Hilum } \\
\hline & 1 artery & 20 & 80 \\
\hline & 2 artreries & 5 & 20 \\
\hline & 2 veins & 23 & 92 \\
\hline & 3 veins & 2 & 8 \\
\hline & 1 Bronchus & 2 & 8 \\
\hline & 2 Bronchii & 23 & 92 \\
\hline & \multicolumn{3}{|c|}{ Left Lungs ( $n=25$ ) } \\
\hline & Feature & No. & $\%$ \\
\hline \multirow{10}{*}{$\begin{array}{l}\text { Table 2: Varia- } \\
\text { tions seen in Left } \\
\text { Lungs. }\end{array}$} & \multicolumn{3}{|l|}{ Oblique Fissure } \\
\hline & Complete & 23 & 92 \\
\hline & Incomplete & 2 & 8 \\
\hline & \multicolumn{3}{|c|}{ Structures in Hilum } \\
\hline & 1 artery & 25 & 100 \\
\hline & 1 vein & 2 & 8 \\
\hline & 2 vein & 21 & 84 \\
\hline & 3 vein & 2 & 8 \\
\hline & 1 bronchus & 18 & 72 \\
\hline & 2 bronchus & 7 & 28 \\
\hline
\end{tabular}

Fig. 2: Incomplete Horizontal fissure of Right Lung.

Fig. 3: Absent Horizontal fissure in Right Lung. 
Fig. 4: Incomplete Oblique Fissure in Left Lung.

Fig. 6: Hilum of Right Lung with One bronchus.
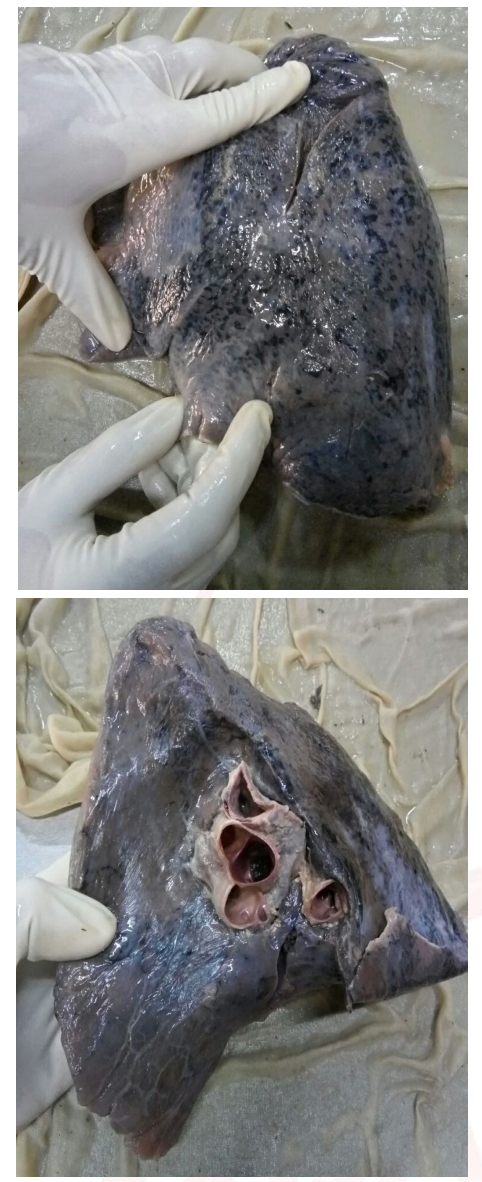

Fig. 5: Hilum of Right Lung with Two arteries.

Fig. 7: Hilum of Left Lung with One vein.
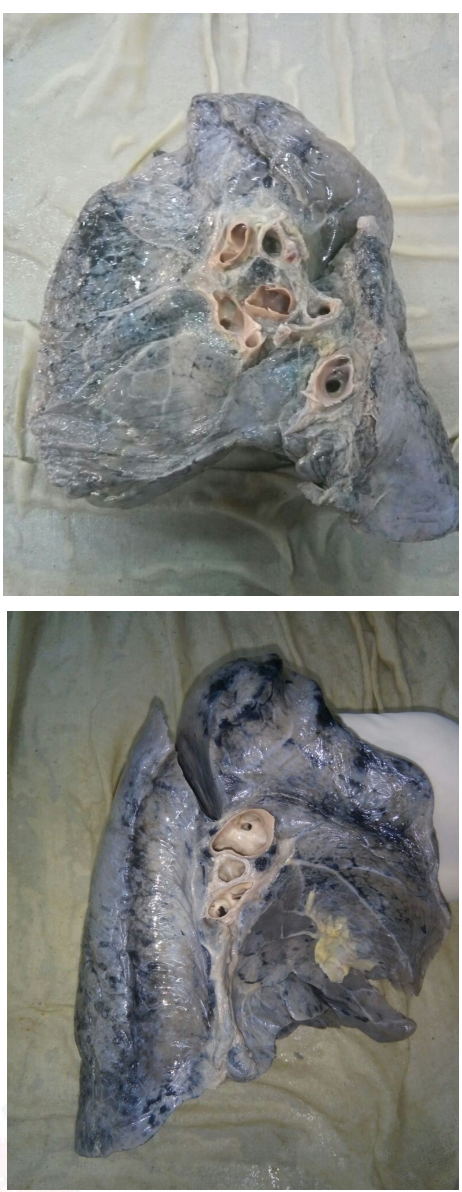

\section{DISCUSSION}

Cadavers are the best means to study variant anatomy of any organ of the body. Various researchers have reported the anomalous anatomy of the lungs in human cadavers.

During development of the Lungs numerous bronchopulmonary buds are formed and later the spaces and fissures between segmentes gets obliterated except along 2 planes, which persist as oblique or horizontal fissure. Incomplete or absent fissure is result of partial or complete obliteration of fissures. Accessory fissure could be the result of non obliteration of spaces which normally are obliterated [4].

In our study we could find few variations of the fissures of the lungs and hilar structures.

Table shows the comparison of previous studies with present study data [5-9].

When compared to the previous studies, we found a higher incidence of Incomplete oblique fissure in left lung. While not a single specimen of lung with absent left oblique fissure. Which was found as $7-15 \%$ in other studies. We did not found even a single case of Absent or incomplete right oblique fissure. We noticed $28 \%$

specimen of lungs with incomplete right horizontal and $8 \%$ with absent right horizontal fissure. Whereas the previous studies report the incidence of this variation as $8-63 \%$.

We found $20 \%$ incidence rate of 2 arteries in right lung Hilum, which is slightly lower than previous studies. Previous studies have reported cases of 1 artery, 3 arteries, 3 bronchus, but we did not found any such cases. In left lung specimens we found $28 \%$ cases with 2 bronchus in hilum which is similar to other studies. We didn't find any cases with 2 arteries, 4 bronchus in left lungs.

Incomplete fissure may alter the spread of disease within the lung. Pneumonia remains within the confines of the particular lobe by complete fissure. In patients with incomplete fissure, it may spread to adjacent lobes through the parenchymal continuation. In some major lung surgeries cause of poatoperative air leakage is due to an incomplete fissure.

Considering above all facts the knowledge of lobar and hilar anatomy of lungs is of great value for clinicians, surgeons and radiologists. 
Table 3: Comparision of variations in fissures of Lungs in different studies.

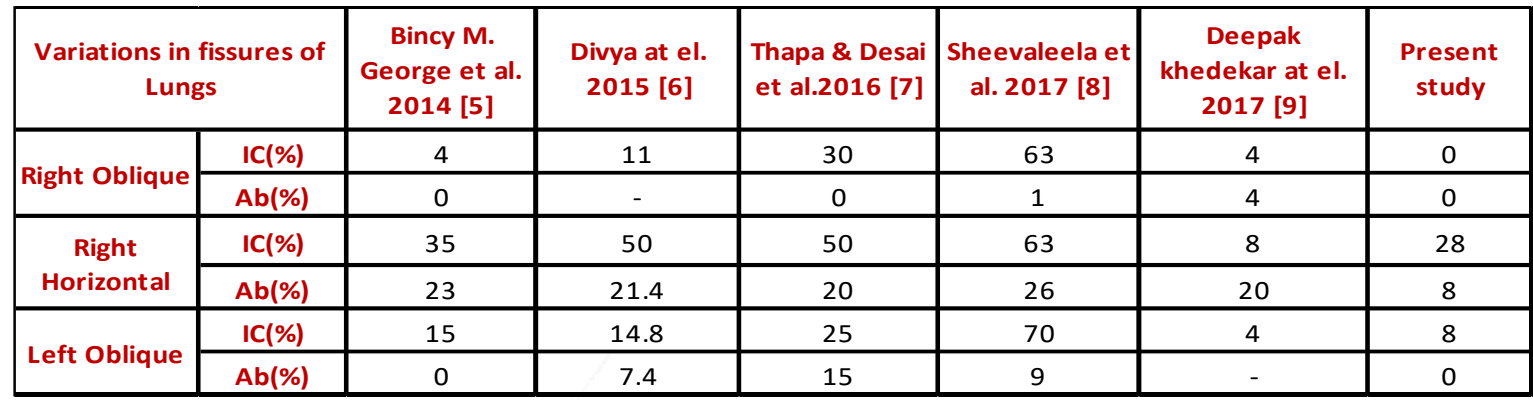

Table 4: Comparison of variations in Hilar structures in different studies.

\begin{tabular}{|c|c|c|c|c|}
\hline \multicolumn{2}{|c|}{$\begin{array}{c}\text { Variations in Hilar } \\
\text { structures }\end{array}$} & $\begin{array}{c}\text { Bincy M. George } \\
\text { et al. 2014 [5] }\end{array}$ & $\begin{array}{c}\text { Deepak khedekar } \\
\text { et el. 2017 [9] }\end{array}$ & Present study \\
\hline \multirow{4}{*}{ Right } & 1 Artery & - & 4 & - \\
\cline { 2 - 6 } & 2 Artery & 67 & 84 & 20 \\
\cline { 2 - 6 } & 3 Artery & 3 & 12 & - \\
\cline { 2 - 5 } & 3 Vein & 32 & 8 & 8 \\
\cline { 2 - 6 } & 1 Bronchus & - & 4 & 8 \\
\cline { 2 - 6 } & 3 Bronchus & 1 & - & - \\
\hline \multirow{5}{*}{ Left } & 2 Artery & 5 & 8 & - \\
\cline { 2 - 6 } & 1 Vein & - & 4 & 8 \\
\cline { 2 - 6 } & 3 Vein & 20 & 4 & - \\
\cline { 2 - 6 } & 2 Bronchus & 22 & 24 & \\
\cline { 2 - 6 } & 4 Bronchus & 2 & 4 & - \\
\hline
\end{tabular}

\section{CONCLUSION}

A sound knowledge of variations in fissures, lobes and hilar anatomy of the lungs is essential clinically while interpreting the radiological images as well as to plan various surgical procedures to avoid postoperative complications. Results of the present study and their comparison with the previous studies shows that a variety of variations can occur in fissures, lobes and hilar structures in human lungs. Earlier researchers have not studied in detail the variations in the hilar structures so this study add a database for the same.

\section{Conflicts of Interests: None}

\section{REFERENCES}

[1]. Shah P,Johnson D,Standring S. Thorax. In: Standring S, editor. Gray's Anatomy: The Anatomical Basis of Clinical Practice. 39th ed. Edinburgh: Churchill Livingstone; 2005. P.1068-69.

[2]. Rosse C, Gaddum-Rose P. Hollinshead's textbook of anatomy. Philadelphia: Lipincott Williams \& Wilkins; 1997. P.441-61.

[3]. Brahmbhatt RJ, Chauhan KB, Bansal M, Brahmbhatt JN. Cadaveric study of azygous lobe of lung. Int J Basic Appl Med Sci 2013;31111;30-3.

[4]. Larsen WJ. Human Embryology. New York; Churchill Livingstone; 1993. P.111-30.

[5]. Bincy M. George, Satheesha B. Nayak, Sapna Marpalli. Morphological variations of the lungs: a study conducted on Indian cadavers. Anat Cell Biol 2014;47:253-8.

[6]. Divya C, Venkateshu KV, Swaroop Raj BV. Anatomical study of pulmonary fissures and lobes. Int J Recent Sci Res 2015;6:4554-7.

[7]. Thapa P, Desai SP. Morphological variation of human lung fissures and lobes: An anatomical cadaveric study in North Karnataka, India. Indian J Health Sci 2016;9:284-7.

[8]. Shivaleela C, Lakshmiprabha S, Afroze MKH. A study of anatomical variations in patterns of fissures and lobes in human lungs: a cadaveric study with clinical significance. Int J Anat Res 2018;6(1.1):481923.

[9]. Deepak Khedekar, Shanta Hattangdi. Morphological variations of the lung: a cadaveric study in mumbai population. Int J Anat Res 2017;5(3.2):4313-16.

\section{How to cite this article: \\ Nishita K Jethva, Hiren S Chavda. A CADAVERIC STUDY ON MOR- PHOLOGICAL VARIATIONS OF LOBAR AND HILAR ANATOMY OF HUMAN LUNGS. Int J Anat Res 2019;7(1.2):6250-6253. DOI: 10.16965/ijar.2018.436}

